\title{
LA RETÓRICA EDAD-IMPUNIDAD EN LOS JUICIOS POR LOS CRÍMENES COMETIDOS DURANTE EL GENOCIDIO ARGENTINO (1975-1983)
}

\section{The age-impunity rhetoric in the trials for crimes committed during the Argentine genocide (1975-1983)}

\section{Lior Zylberman}

CONICET, Centro de Estudios sobre Genocidio, Universidad Nacional de Tres de Febrero

Adriana Taboada*

Centro de Estudios sobre Genocidio, Universidad Nacional de Tres de Febrero

\begin{abstract}
Palabras clave
Juicio

Impunidad

Viejismo

Fotografía a una forma de impunidad que puede ser denominada como «impunidad gerontológica». Para adentrarnos en la construcción de esa representación, pondremos en tensión el par visto/no visto a través de fotografías y editoriales de la prensa escrita, siendo nuestros principales puntos de anclaje teórico el concepto de "viejismo" aportado por la gerontología y la "fórmula del martirio" que surge del estudio de las representaciones de masacres y genocidios desarrollado por José Emilio Burucúa y Nicolás Kwiatkowski.
\end{abstract}

RESUMEN: Desde la reapertura de los juicios por los crímenes cometidos por la última dictadura militar en Argentina, han emergido nuevos aspectos en la escena judicial, siendo uno de ellos la "retórica edad-impunidad». En su dimensión visual, entendemos por dicha retórica a la representación de los perpetradores que ha ido tomando forma en los últimos años, habilitando la posibilidad de eximirlos de culpa y responsabilidad por los crimenes cometidos en virtud de su avanzada edad. Sostenemos que lo visual configura una determinada estética que brinda andamiaje a la impunidad y su naturalización, dando lugar

ABSTRACT: Since the reopening of the trials for the crimes committed by the last military dictatorship in Argentina, new aspects have emerged in the judicial scene, one of them being the "age-impunity rhetoric". In its visual dimension, we understand this rhetoric to mean the representation of the perpetrators that has been taking shape in recent years, enabling them to be exempted from guilt and responsibility for the crimes committed by virtue of their advanced age. We argue that the visual configures a certain aesthetic that provides a scaffolding for impunity and its naturalization, giving rise to a form of impunity that can be termed "gerontological impunity". In order to enter into the construction of this representation, we will put in tension the pair seen/unseen through photographs and editorials in the written press. Our main theoretical anchor points are the concept of ageism proposed by gerontology and the "formula of martyrdom" that arises from the study of the representations of massacres and genocides developed by José Emilio Burucúa and Nicolás Kwiatkowski.

\footnotetext{
* Correspondencia a/Correspondence to: Adriana Taboada. CONICET, Universidad Nacional de Tres de Febrero, Suipacha 927, puerta2, piso 2, Buenos Aires, Argentinaadrianatabo@gmail.com - http://orcid.org/0000-0003-2740-3339.

Cómo citar / How to cite: Zylberman, Lior; Taboada, Adriana (2021). «La retórica edad-impunidad en los juicios por los crímenes cometidos durante el genocidio argentino (1975-1983)». Papeles del CEIC, vol. 2021/2, papel 249, 1-23. (http://doi.org/10.1387/pceic.22352).
}

Fecha de recepción: diciembre, 2020 / Fecha aceptación: junio, 2021.

ISSN 1695-6494 / (c) 2021 UPV/EHU 
La legítima aspiración de que se haga justicia por los crímenes cometidos durante el genocidio perpetrado en Argentina entre 1975 y 1983, nos interpela y convoca a pensar sobre nuevos aspectos que van haciendo su ingreso a la escena judicial y que tienen impacto sobre dicha aspiración.

En el presente trabajo nos proponemos reflexionar sobre uno de estos aspectos vinculado a la dimensión del discurso visual del proceso de juzgamiento, y al que denominamos uretórica edad-impunidad». Entendemos por retórica edad-impunidad en su dimensión visual, a la representación de los perpetradores ${ }^{1}$ que ha ido tomando forma en los últimos años ${ }^{2}$, habilitando la posibilidad de eximirlos de culpa y responsabilidad por los crimenes cometidos en virtud de su avanzada edad. Podríamos decir que lo visual configura una determinada estética que brinda andamiaje a la impunidad y su naturalización, dando lugar a una forma de impunidad que puede ser llamada «impunidad gerontológica» (Programa Verdad y Justicia, 2015).

Para adentrarnos en la construcción de esa representación pondremos en tensión el par visto/no visto a través de fotografías y editoriales de la prensa escrita, siendo nuestros principales puntos de anclaje teórico el concepto de viejismo aportado por la gerontología (Butler, 1969; Salvarezza, 1996) y la "fórmula del martirio" que surge del estudio de las representaciones de masacres y genocidios desarrollado por José Emilio Burucúa y Nicolás Kwiatkowski (2014).

\section{RECORRIDO HISTÓRICO Y MARCO LEGAL}

En diciembre de 1983 se inicia un nuevo ciclo democrático en la Argentina luego de la caída del Proceso de Reorganización Nacional (PRN), nombre con el que se autodenominó la última dictadura militar que gobernó entre $1976^{3}$ y aquel año. A diferencia de otras dictaduras que quebraron el orden democrático ${ }^{4}$, el PRN logró imponer un modelo económico neoliberal. Para alcanzar este objetivo implementó un plan sistemático de violación de los derechos humanos que incluyó el secuestro, tortura y asesinato de miles de personas dejando un saldo de 30.000 desaparecidos, más de 700 Centros Clandestinos de Detención, Tortura y Exterminio (CCDTyE) 5 diseminados a lo largo de todo el país, aproximadamente 500 bebés apropia-

1 Para un abordaje general sobre el estudio de los perpetradores, véase la presentación al presente número monográfico coescrita por uno de los autores del presente artículo.

2 Durante el periodo 1987-2005 legalmente quedó impedido el juzgamiento de los hechos producidos durante 1976-1983. Esta situación se revirtió en el año 2005.

3 Siguiendo los desarrollos de Daniel Feierstein (2007) el genocidio argentino se inicia durante el gobierno democrático de Isabel Martínez de Perón, el 9 de febrero de 1975, fecha en que comienza el Operativo Independencia en Tucumán. En una escuela del pueblo de Faimallá (Tucumán), se abre el primer centro clandestino de detención, conocido como Escuelita de Famillá. Un año después, el 24 de marzo de 1976, se produce el golpe militar y se instala una dictadura.

4 En la Argentina se produjeron golpes de estado en los años 1930, 1943, 1955, 1962, 1966 y 1976.

5 En los CCDTyE se incluía la posibilidad de materializar la muerte y resolver qué hacer con los cuerpos. Un ejemplo de ello lo encontramos en el de la Escuela de Mecánica de la Armada (ESMA), que contó con aviones desde los que arrojaron al mar a los desaparecidos, acción conocida como Vuelos de la Muerte. 
dos, muchos de ellos nacidos durante el cautiverio de sus madres ${ }^{6}$, más de 10.000 presos y presas políticas y cientos de miles de exiliados y exiliadas. Para cambiar el patrón de acumulación, base de un nuevo modelo económico, el PRN transformó las relaciones sociales desplegando una política de terror y persecución y exterminando a una parte de su población. Este proceso se vio acompañado además por un relato que hablaba de la «vigencia de los valores de la moral cristiana, de la tradición nacional y de la dignidad del ser argentino" (Junta Militar, 1980: 8).

Cuando asume el nuevo gobierno democrático en 1983, se produce algo inédito: se crea la Comisión Nacional sobre la Desaparición de Personas ${ }^{7}$ y se ordena llevar a juicio a quienes integraron las cuatro Juntas Militares que gobernaron el país entre 1976 y 1983 . Ante la negativa del Consejo Supremo de las Fuerzas Armadas de enjuiciar a sus pares, dicho proceso lo llevó adelante la Cámara Nacional de Apelaciones en lo Criminal y Correccional Federal de la Capital Federal, un tribunal civil. De este modo, entre abril y diciembre de 1985, tuvo lugar el denominado "Juicio a las Juntas», donde por primera vez en la historia argentina se juzgó a responsables de una dictadura militar por los crimenes cometidos. Ese juicio también es conocido como "Causa 13 " y en su sentencia el tribunal descarta la existencia de una guerra, relato sostenido por las diversas juntas militares que estuvieron al frente del PRN, y da por probada la organización, características metodológicas y sistematicidad del plan criminal que se desplegó en el país. Asimismo, y de manera inesperada, estableció continuar con el proceso de juzgamiento a miembros de las Fuerzas Armadas y de Seguridad, siguiendo la cadena de mandos.

Sin la decisión política del gobierno de Raúl Alfonsín de avanzar en ese sentido y bajo la presión de los sectores militares ${ }^{8}$, en 1986 y 1987 se sancionaron las leyes conocidas como de Punto Final ${ }^{9}$ y de Obediencia Debida ${ }^{10}$, que trascendieron bajo la denominación de Leyes de Impunidad, pues impidieron legalmente continuar con los procesos de juzgamiento ${ }^{11}$. Durante 1989 y 1990 a este escenario se sumaron los indultos firmados por el entonces presidente Carlos Menem, por los cuales se perdonó el cumplimiento de las penas, entre otros, a los miembros de las juntas militares condenados en el juicio de 1985, quienes a partir de ese momento quedaron en libertad.

6 La mayoría de las familias que se apropiaron de estos bebés, eran parte o allegados a las diversas Fuerzas Armadas y de Seguridad.

7 Creada por decreto cinco días después de asumir las nuevas autoridades democráticas, el objetivo de la comisión fue investigar las reiteradas y planificadas violaciones a los derechos humanos ocurridas durante la última dictadura. Dicha comisión fue conformada con reconocidas personalidades del ámbito de la cultura, la ciencia, el derecho, el periodismo, religioso y del movimiento de los derechos humanos. En su informe publicado en 1984 con el título Nunca Más, dio cuenta de las características y sistematicidad de los crímenes de la dictadura bajo la lógica secuestro-tortura-muerte.

8 Dado que la sentencia del juicio a las Juntas establecía continuar con el proceso de justicia siguiendo la cadena de mandos, y la instrucción judicial avanzaba en ese sentido, miembros de las Fuerzas Armadas de menor graduación organizan la resistencia al mismo. Se produjeron varios alzamientos entre 1987 y 1990, conocidos como Levantamientos Carapintadas, porque los militares se pintaron el rostro como en la guerra.

9 La Ley 23.492 de Punto Final estableció la caducidad de la acción penal (prescripción) contra los imputados como autores penalmente responsables de haber cometido el delito complejo de desaparición forzada de personas que tuvieron lugar durante el PRN que no hubieran sido llamados a declarar «antes de los sesenta dias corridos a partir de la fecha de promulgación de la presente ley». La ley se sancionó el 24/12/86.

10 La Ley 23.521 de Obediencia Debida estableció la presunción que los delitos cometidos por los miembros de las Fuerzas Armadas cuyo grado estuviera por debajo de coronel , durante el terrorismo de Estado y la dictadura militar no eran punibles, por haber actuado en virtud de la denominada «obediencia debida».

11 La ley de Obediencia Debida estableció que la misma no podría aplicarse para los casos de apropiación de menores o de inmuebles de desaparecidos, por ello esas causas pudieron avanzar. 
Cerrado el camino legal dentro de nuestras fronteras, en la década de 1990 las víctimas trasladaron la lucha por justicia a los espacios internacionales. Una vía fue la búsqueda de enjuiciamiento en países como Italia y Francia, entre otros, por víctimas de esas nacionalidades en Argentina, que culminaron en condenas en ausencia. Otro camino fue abierto por Carmen Lapacó, madre de una desaparecida, que realizó una presentación ante la Comisión Interamericana de Derechos Humanos (CIDH) amparándose en el derecho a conocer la verdad sobre lo sucedido con su hija y su derecho a procesar el duelo ante su pérdida. Esta presentación logró que en el año 1999 se firmara un acuerdo amistoso entre Lapacó y el Estado argentino para avanzar sobre el tema de la verdad. Mientras tanto, desde 1998, en distintas jurisdicciones del país se comenzaron a realizar los Juicios por la Verdad, procedimiento judicial sin efectos penales que permitió escuchar el testimonio de cientos de víctimas, familiares, militares y miembros de las fuerzas de seguridad ${ }^{12}$. En los siguientes años se fueron sumando otros logros que permitieron la anulación de las leyes de impunidad por parte del Congreso de la Nación (2003) y la declaración de la inconstitucionalidad de aquellas por parte de la Corte Suprema de Justicia (2005) quien también declarará la imprescriptibilidad de los delitos cometidos en la década de 1970.

A 30 años de aquellos hechos, y casi 20 bajo el imperio de la impunidad legalizada, pudo retomarse el camino judicial. Hoy, luego de 15 años de juicios, hay 246 sentencias en primera instancia, juicios llevados adelante por tribunales locales y civiles, sostenidos en legislación nacional y con el código de procedimientos procesal penal argentino. Suman 3.329 personas investigadas por delitos de lesa humanidad, de las cuales 618 son personas procesadas, 538 imputadas, a 176 se les dictó la falta de mérito, 162 fueron absueltas, 92 sobreseídas, 65 indagadas, hay 28 prófugos y ascienden a 997 los condenados ${ }^{13}$.

A pesar de la contundencia de este proceso, la reapertura de los juicios fue $-y$ sigue siendocuestionada por algunos sectores de la sociedad, sobre todo los más conservadores, allegados a las fuerzas armadas y de seguridad y, por supuesto, por el poder económico. Ya en el año 2003 el diario conservador La Nación ${ }^{14}$ manifestaba en un editorial que la reapertura de los juicios sería una "decisión gravísima» y que serían un obstáculo para avanzar "por los caminos de la reconciliación y la plena recomposición de la paz socialı ${ }^{15}$. Desde ese momento, y hasta el presente, estos sectores han ido desarrollando distintas alternativas para evitar la investigación, procesamiento o juzgamiento de miembros de las fuerzas armadas y de seguridad, empresarios, civiles y eclesiásticos acusados por su responsabilidad criminal en el genocidio, en connivencia con el Poder Judicial. Cuando ese objetivo no se logra buscan alternativas para obtener su libertad o alcanzar medidas que morigeren el cumplimiento de las penas ${ }^{16}$.

12 Mucho de lo producido durante esos juicios se incorporó como prueba cuando se reabren los procesos judiciales en 2005.

13 Datos extraídos de: https://www.fiscales.gob.ar/lesa-humanidad/argentina-llega-a-las-casi-mil-personas-condenadas-por-haber-cometido-delitos-de-lesa-humanidad-durante-el-terrorismo-de-estado/. Última consulta: 26/07/2021.

14 El diario La Nación es una de las publicaciones más tradicionales de la Argentina. Fundado en 1870, desde su origen mantiene una línea editorial y política de corte liberal-conservadora.

15 Disponible en: https://www.lanacion.com.ar/editoriales/una-decision-gravisima-nid519397/. Última consulta: 01/11/2020.

16 Cuando hablamos de alcanzar la libertad a pesar de estar investigados, procesados o condenados nos referimos a la aplicación del art. 77 del Código Procesal Penal Nacional (CPPN), conocido como de «incapacidad sobreviniente». Este articulado establece que «si durante el proceso sobreviniere la incapacidad mental del imputado, el tribunal suspenderá la tramitación de la causa. (...). La suspensión del trámite del proceso impedirá la declaración indagatoria o el juicio, según el momento que se ordene». Esto quiere decir que, si se com- 


\section{VIEISSMO}

Los juicios por delitos de lesa humanidad que se desarrollan en Argentina desde el año 2006 tienen como acusados y condenados a una población numéricamente importante y añosa, por lo que la edad se ha convertido en un dato relevante con impacto en ese proceso (Taboada, 2016). En 1969 el psiquiatra norteamericano Robert Butler acuñó el término ageism, neologismo traducido al español como "viejismo», y que se refiere al conjunto de estereotipos, prejuicios y discriminaciones que se aplican a los adultos mayores exclusivamente en función de su edad. Conceptualmente el "viejismo" nos introduce entonces en el proceso de envejecimiento, la declinación vital y la vejez.

La vejez es una categoría cultural, mientras que el envejecimiento es una categoría biológica. El envejecimiento es un proceso que se desarrolla a lo largo de toda la vida y culmina con la muerte. Es natural, universal y avanza en el sentido de la declinación. Puede ser prematuro o tardío, acelerarse o lentificarse en función de la base genética, los recursos psíquicos, los factores ambientales, el sostén social, las condiciones materiales de existencia y el tipo de vida que se ha llevado, pero en la medida en que es inevitable e irreversible, solo podemos actuar sobre sus efectos. Como no es una afección clínica, no se pueda prevenir o evitar. La vejez tampoco es una enfermedad sino una etapa etárea, la última del ciclo de la vida y dónde el envejecimiento se profundiza.

Los cambios culturales producidos a partir de la segunda mitad del siglo pasado fueron transformando el modelo de vejez, dando lugar a una representación negativizada y sujeta a discriminación, donde es posible reconocer el «viejismo». En esa dirección, diremos que el viejismo es una creencia (Salvarezza, 1996), y como tal es un proceso activo que tiene consecuencias: "hacen surgir sentimientos, influyen en las percepciones y promueven acciones» (Britton, 1994: 27). La creencia precede a la "evaluación objetiva» de que las personas de edad más avanzada son sujetos incapaces, habilitando que el viejismo nos haga pensar la vejez como sinónimo de enfermedad, dependencia, incapacidad, aislamiento y deterioro cognitivo. El viejo será entonces alguien con actitudes de niño, que no entiende, tacaño, mezquino, malhumorado, improductivo, desmemoriado, senil, inválido, feo, desvitalizado y asexuado.

Esta creencia forma parte de una matriz no consciente pero activa desde la cual miramos, damos razones, sacamos conclusiones y decidimos acciones respecto de los adultos mayores y de nosotros mismos llegados a esa etapa de la vida.

A partir de lo dicho, otro aspecto que resulta relevante para nuestro trabajo es la relación entre salud y vejez. Desde la década de 1980, la Organización Mundial de la Salud (OMS) y la Organización Panamericana de la Salud (OPS) han ido introduciendo cambios en la definición de la salud, incorporando la "perspectiva funcional" para pensar la misma en el caso de los adultos mayores, entendiendo por tal la capacidad para enfrentar los cambios manteniendo

prueba que se ha producido una incapacidad, la persona ya no podrá ser juzgada y si estaba condenada, queda libre. Respecto del cumplimiento morigerado de la pena, este se vincula al art. 32 de la ley 24660 que establece que «el Juez de ejecución, o juez competente, podrá disponer el cumplimiento de la pena impuesta en detención domiciliaria». Luego enumera causales entre las que se encuentra ser mayor de 70 años. Lo importante aquí es que la ley utiliza la conjugación verbal podrá y no deberá, pero en los hechos la gran mayoría de los jueces y juezas otorgan el beneficio de manera casi automática. 
la adaptación y satisfacción personal (OMS, 2015: 30) ${ }^{17}$. Desde esta concepción, el indicador privilegiado para evaluar la salud pasó a ser la «independencia funcional» y no la ausencia de enfermedad. Por lo tanto, más importante que la presencia de patología o deterioro es establecer en qué medida esta impide o interfiere en la actividad normal del adulto mayor ${ }^{18}$.

A partir de lo expuesto, desarrollaremos lo que hemos denominado retórica edad-impunidad, una forma de narración particular vinculada a los acusados o condenados por delitos de lesa humanidad que será abordada desde el binomio visto/no visto y la tensión que se produce entre ambos. Esta tensión será entonces el insumo elegido para pensar la construcción de representaciones que alimentarán esa narración.

Los editoriales o notas de opinión de la prensa escrita son las expresiones que nos permitirán el análisis de lo no visto mientras que para el análisis de lo visto, la otra dimensión del binomio, tomaremos una serie de fotografías relacionadas con los juicios que han circulado en la esfera pública.

\section{LA RETÓRICA EDAD-IMPUNIDAD A PARTIR DE LO NO VISTO: PRIMERA APROXIMACIÓN}

Como decíamos, los editoriales o notas de opinión de la prensa escrita nos permitirán adentrarnos en este primer nivel de análisis. Ambas se construyen sólo desde la palabra, y desde ella promueven la construcción y reconstrucción de imágenes de índole inmateriales (es decir, que no tienen un soporte físico como, por ejemplo, la fotografía). Podemos pensar que este tipo de imágenes se encuentran próximas a la noción de representaciones sociales. En esa dirección, Denise Jodelet (1984) entiende por representaciones sociales a una forma de conocimiento específico - el saber del sentido común-, que va constituyendo modalidades de pensamiento práctico orientados hacia la comunicación, la comprensión y el dominio del entorno social. Para que las representaciones sociales sean concebidas como imágenesconceptos, deben efectuar dos operaciones: de un lado, la objetivización, y del otro, el anclaje. La primera se define como una operación estructurante formadora de imagen mental; mientras que la segunda se refiere al enraizamiento social de la representación y su objeto. En otras palabras, la primera operación permite uponer en imágenes las nociones abstractas [haciendo] corresponder cosas con palabras» (Jodelet, 1984: 481); y la segunda, traduce la imagen abstracta en significado y utilidad, permitiendo así una integración cognitiva de lo representado en la vida social cotidiana. Para ejemplificar la potencia de esta perspectiva en la problemática de nuestro trabajo, pensemos lo siguiente: si nunca hemos estado en una cárcel, sobre todo en un pabellón para presos por delitos de lesa humanidad en Argentina, ¿qué ideas o qué imágenes tendremos de ella? Nuestro imaginario sobre la misma se configurará

17 Para una definición del término envejecimiento saludable por parte de la OPS, véase: https://www3.paho.org/ hq/index.php?option=com_content\&view=article\&id=13634:healthy-aging\&ltemid=42449\&lang=es. Última consulta: $1 / 7 / 2021$.

18 Lo planteado no niega la existencia del envejecimiento patológico y en particular la aparición de demencias, las cuales abren todo un capítulo en geriatría, pues esta patología es una de las más utilizadas por los genocidas para intentar quedar comprendidos en el art. 77 del CPPN. No obstante, en la mayoría de los casos la evaluación pericial en salud no arriba a ese diagnóstico, y sí en cambio al de simulación. 
seguramente a partir de películas, series de televisión u otras ideas; en consecuencia, las imágenes que surgen asocian a las cárceles con lugares oscuros, de espacio reducido y sucio y con gruesos barrotes. Incluso quizá también imaginemos a los presos con uniformes a rayas. Consideramos entonces que las representaciones sociales que se construyen sobre los presos por delitos de lesa humanidad y sus condiciones de existencia carcelaria se apoyan en lo no visto, en lo que no se muestra. Como sostendremos a continuación, la retórica edad-impunidad basa parte de su argumentación en esta perspectiva, operando sobre y con las representaciones sociales sobre la cárcel.

Como parte de su política editorial, desde la reapertura de los juicios el diario La Nación ha publicado editoriales o notas de opinión contraria a los mismos, reclamando su rápida finalización, la "reconciliación nacional» o la "memoria completa» ${ }^{19}$. El 15 de agosto de 2003, cuando el Congreso Nacional se aprestaba a anular las Leyes de Impunidad, La Nación publicó el editorial "Una decisión gravísima» ${ }^{20}$. En ella, afirmaba que "la anulación de una ley por el mismo órgano que la dictó consagra un absurdo en materia constitucional», resultando «indispensable que los argentinos, sin negar los capítulos aciagos y dolorosos de nuestra historia reciente, procuremos avanzar por los caminos de la reconciliación y la plena recomposición de la paz social»; así, manifestándose en contra de la posible reapertura de los procesos judiciales, el editorial señalaba que «no se debe permitir que se reabran las heridas del pasado ni que resuciten los odios que ensangrentaron en otro tiempo la vida argentina». De este modo, este diario se convirtió muy pronto en tribuna y portavoz del sector de la sociedad que se ha manifestado en contra de los juicios; y aunque familiares de miembros de las fuerzas armadas y de seguridad y otros organismos que se posicionaron en contra de los procesos han editado diversas publicaciones y sitios web, estas tienen escasa difusión y carecen de la tirada y prestigio que sí posee La Nación ${ }^{21}$.

A medida que los juicios avanzaron y las condenas en cárceles comunes se volvieron firmes, La Nación continuó manifestándose por una "memoria completa» y por crear "caminos de reconciliación»; en esa línea, entendía que los juicios tal como se estaban llevando adelante eran actos de venganza y no de justicia. Así, en una editorial de octubre de 2013 comenzó a reclamar por la concesión de la prisión domiciliaria a los condenados por delitos de lesa humanidad"22. En dicho editorial, titulada "Cuando la justicia se convierte en venganza», se afirmaba que los condenados se encuentran en condiciones deplorables, carecen de higiene y alimentación como de atención médica; exigiendo así cumplir con la ley de prisión domiciliaria. Un año después, en noviembre de 2014, La Nación publica un editorial similar con el mismo reclamo. Bajo el título «Al enemigo, ni justicia... ni derechos humanos», la editorial «denuncia» el «maltrato a los presos de edad avanzada en causas vinculadas con la lucha contra la subversión». Al día siguiente que la alianza Cambiemos ganó las elecciones presidenciales de 2015, el mismo diario se manifestó en una editorial reclamando la finali-

19 La «memoria completa» se refiere a una tendencia revisionista, sobre todo de sectores afines a la última dictadura, que pretende igualar la memoria de las víctimas con las de los represores. Al respecto, véase: Salvi (2012).

20 Disponible en: https://www.lanacion.com.ar/editoriales/una-decision-gravisima-nid519397. Última consulta: 01/11/2020. La Nación se manifestó de manera temprana a la revisión de las leyes e indultos en el año 2001. Sobre el tratamiento de los periódicos a los Juicios, véase la tesis de Natalia Crocco (2020).

21 Como señalan Marcelo Borrelli y Mercedes González (2012), el 57\% los lectores de La Nación pertenecen a los segmentos de mayor poder adquisitivo. También destacan que entre sus lectores se encuentran muchos militares retirados en ejercicio de sus funciones durante la dictadura militar.

22 Disponible en: https://www.lanacion.com.ar/editoriales/cuando-la-justicia-se-convierte-en-venganzanid1625363. Última consulta: 01/11/2020. 
zación de los juicios: así, bajo el título de «No más venganza», el diario planteaba algunas cuestiones que el nuevo gobierno debería resolver siendo una de ellas "el vergonzoso padecimiento de condenados, procesados e incluso de sospechosos de la comisión de delitos cometidos durante los años de la represión subversiva y que se hallan en cárceles a pesar de su ancianidad, [constituyendo esto] una verdadera vergüenza nacional» ${ }^{23}$. La política judicial de concesión de las prisiones domiciliarias como modo de morigeración de la pena ${ }^{24}$ se ha sostenido y profundizado en los últimos años ${ }^{25}$, sin embargo, La Nación, siguió apremiando para que la misma sea efectiva a todos los condenados; así, en una columna de opinión del 21 de noviembre de 2016, el columnista manifestaba que la prisión domiciliaria a condenados por delitos de lesa humanidad es un derecho indiscutible y que no admite "otra interpretación»".

Estas notas de prensa nos sirven para realizar varias observaciones. En primer lugar, no hay imágenes fotográficas en estas noticias del medio gráfico - los editoriales no las llevan- ni encontramos notas con imágenes en el cuerpo del diario. Esto nos conduce al vínculo entre imagen mental y representación social que antes mencionáramos: el texto escrito genera en el lector las imágenes sobre estos perpetradores y las condiciones carcelarias en que se encuentran. En segundo lugar, debemos detenernos en el modo en que juega el concepto de viejismo para los condenados o imputados por estos crímenes. En los editoriales mencionados se asocia vejez con fragilidad, enfermedad, maltrato o precariedad, en otras palabras, los editoriales recurren de manera consciente a los diversos estereotipos de la vejez que antes mencionábamos. Respecto de las cárceles, las imágenes mentales que quizá surjan en los lectores al leer estas notas seguramente contendrán elementos que refieren a la representación social que comúnmente nos hacemos de ellas y que antes mencionamos: barrotes, oscuridad, espacios reducidos, abandono y maltrato. En consecuencia, las imágenes que se crean y se ponen en circulación respecto de los imputados o condenados por crímenes contra la humanidad es la de viejos-ancianos-abuelitos enfermos y decrépitos, viviendo en espacios reducidos, oscuros, sucios y enrejados, sometidos al abandono del sistema y sin respeto por sus derechos. Empatía mediante, esas imágenes despiertan emociones ligadas a la vulnerabilidad, la desprotección e incluso a la piedad. Sostenemos así que las palabras y las imágenes convocadas van construyendo un discurso que instituye un tipo de retórica de impunidad particular ${ }^{27}$ donde los imputados o condenados ya no son criminales, represores o genocidas sino "abuelitos» enfermos y deteriorados sometidos a los abusos y abandono del sistema. "La vejez» reemplaza "al crimen", produciendo así un efecto casi de borramiento que va dejando fuera de escena las características y particularidades de los crímenes que cometieron y por los cuales efectivamente han sido o podrian ser condenados por la justicia.

Los procesados o condenados a lo largo de estos 15 años de juicios, más allá de sus arrugas, sus ritmos lentos, bastones o dificultades de movimiento, sostienen su capacidad como hom-

23 Disponible en: https://www.lanacion.com.ar/opinion/no-mas-venganza-nid1847930. Última consulta: $01 / 11 / 2020$.

24 El art. 32 de la ley 24660 ya citado.

25659 personas cumplen arresto domiciliario, lo que representa el 72\% de los casos. Disponible en: https://www. fiscales.gob.ar/lesa-humanidad/argentina-llega-a-las-casi-mil-personas-condenadas-por-haber-cometidodelitos-de-lesa-humanidad-durante-el-terrorismo-de-estado/. Última consulta: 01/09/2020.

26 Disponible en: https://www.lanacion.com.ar/opinion/el-derecho-a-la-detencion-domiciliaria-nid1958014. Última consulta: 01/11/2020.

27 Distinta de la impunidad que habilitaron las leyes de Punto Final y Obediencia Debida imposibilitando que los juicios tuvieran lugar. 
bres autónomos que toman decisiones. Con muy pocas excepciones, ningún acusado se dispuso a brindar información fehaciente y concreta sobre los desaparecidos, el destino de sus cuerpos o sobre los recién nacidos apropiados. Ser viejos no les impide tener plena conciencia de su accionar pasado y seguir sosteniendo en el presente el pacto de silencio o de sangre esgrimido por las fuerzas armadas y de seguridad; es más, en su justificación suelen reivindicar y recordar -en pleno uso de sus facultades mentales- lo que manifestaron en el denominado Documento Final: que el accionar de los integrantes de las Fuerzas Armadas son actos de servicio y que dichos actos quedan «sujetos al juicio de Dios» - y no al juicio de los hombres-y «a la comprensión de los hombres» ${ }^{28}$.

\section{LA RETÓRICA EDAD-IMPUNIDAD A PARTIR DE LO VISTO: LA FÓRMULA DEL MARTIRIO}

La segunda dimensión del binomio, lo visto, la analizaremos a partir de una serie de fotografías de perpetradores en el escenario judicial, que han circulado en la esfera pública.

La fotografía, como toda imagen, en un mismo movimiento materializa presencias y ausencias; es por ello por lo que la imagen fotográfica no es ni transparente ni una «ventana a la realidad», sino un código a ser interpretado. A un mismo tiempo las fotografías visibilizan e invisibilizan, configurando una tensión que puede ser pensada desde el plano de las representaciones.

José Emilio Burucúa y Nicolás Kwiatkowski han analizado las representaciones construidas sobre las masacres y genocidios desarrollando el concepto de fórmulas de representación. Por este constructo los autores reconocen a unn conjunto de dispositivos culturales que han sido conformados históricamente $y$, al mismo tiempo, gozan de cierta estabilidad, de modo que son fácilmente reconocibles por el lector o el espectador» (2014: 46); sugieren que es más amplia que una metáfora y que un topos - aunque suelen recurrir a ambos para representar un tema determinado- y que también difieren de las Pathosformel warburgianas ${ }^{29}$ al ser "más en número y más cambiantes» (Burucúa y Kwiatkowski, 2014: 46). De las fórmulas establecidas por los autores, nos interesa concentrarnos en la «fórmula del martirio».

El significado de la palabra mártir proviene de martus, que en latín designa a una persona que atestigua sobre un hecho conocido a partir de su propia experiencia, dicha acepción es la que predominará en los textos cristianos. Así, un mártir es «una persona que, incluso aunque nunca haya visto o escuchado al divino fundador de la Iglesia, está tan convencido de las verdades de la religión cristiana que acepta la muerte con tal de no negarlas» (Burucúa y Kwiatkowski, 2014: 96). De allí, el término fue aplicándose cada vez más, y de manera ex-

28 El Documento Final de la Junta Militar sobre la guerra contra la subversión y el terrorismo fue presentado en abril de 1983 meses antes de las elecciones presidenciales. En ese informe las Fuerzas Armadas ofrecían una justificaron de su propio accionar, presentándolo como una "guerra» de consecuencias dolorosas pero inevitables, en la que, "como en toda guerra», se habrían cometido algunos «errores y excesos». Había sido, en consecuencia, una "guerra sucia».

29 El historiador de arte Aby Warburg utilizó el término Pathosformel para nombrar las formas expresivas intensificadas o superlativas que encontró en el arte antiguo - el griego y el romano- y que se incorporaron a las obras de los artistas del Renacimiento en la creación de un estilo. 
clusiva, a quienes murieron por la fe y sus creencias; en consecuencia, la persecución puede ser entendida como una prueba divina para los creyentes que sólo puede ser superada mediante el martirio y el sacrificio: la muerte debe ser aceptada en lugar de abjurar y negar las creencias. A partir de esta premisa, los autores analizarán desde pinturas y frescos hasta crónicas y memorias

La fórmula del martirio nos permite ingresar en el análisis de la retórica edad-impunidad a partir de una serie de fotografias donde es posible observar a los represores con ornamentación religiosa, más específicamente con cruces. En efecto, en términos discursivos el PRN basó parte de sus fundamentos en la retórica cristiana ${ }^{30}$, y en el marco de los juicios, algunos represores son vistos por ciertos sectores afines a la dictadura -y también se perciben así mismos - como verdaderos mártires. De este modo, en tanto que mártires, los represores parecerian estar dispuestos a soportar el peso de las consecuencias de "sus ideales" sobre todo su cuerpo, y los espectadores, a cambio, al observar dichos cuerpos martirizados no tendrían otra opción que sentir piedad.

Aunque las notas editoriales y de opinión no fueron ilustradas con imágenes, lo cierto es que se han tomado y han circulado numerosas fotografías de los represores en los juicios. Estas imágenes han sido publicadas en diversos medios de comunicación, y también han sido recogidas por sitios web afines a las fuerzas armadas y las organizaciones que defienden su accionar. A continuación, véanse las siguientes fotos:

\section{Figura 1}

Reynaldo Bignone (centro en segunda línea). Séptimo juicio de la causa «Campo de Mayo» (2012)

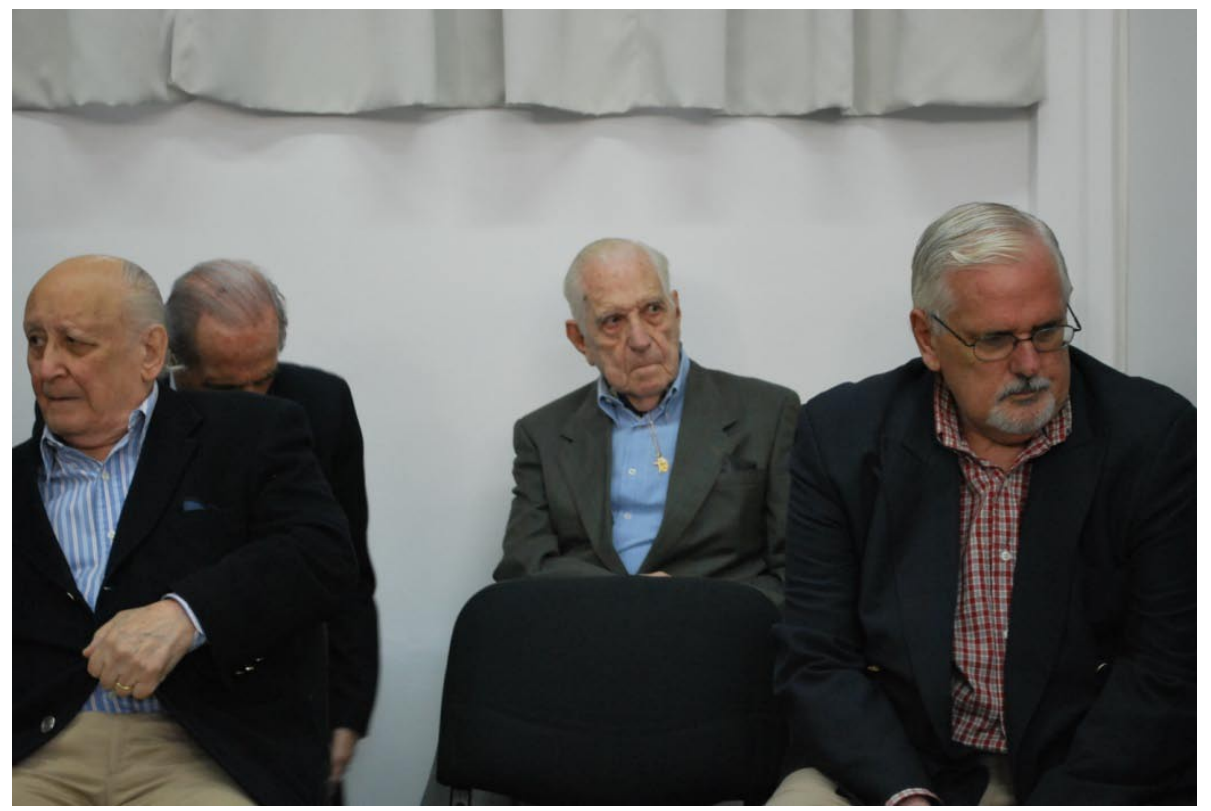

Autora de la foto: Marisú Hernández.

30 En los objetivos básicos planteados por el PRN en su acta del 24 de marzo de 1976, el objetivo 2.2 señala la «vigencia de los valores de la moral cristiana, de la tradición nacional y de la dignidad del ser argentino", mientras que el 2.9, subraya la «ubicación internacional en el mundo Occidental y cristiano, manteniendo la capacidad de autodeterminación, y asegurando el fortalecimiento de la presencia argentina en el concierto de las naciones». 
Figura 2

Jorge Videla en la prisión de encausados de "Campo de Mayo» (2011)

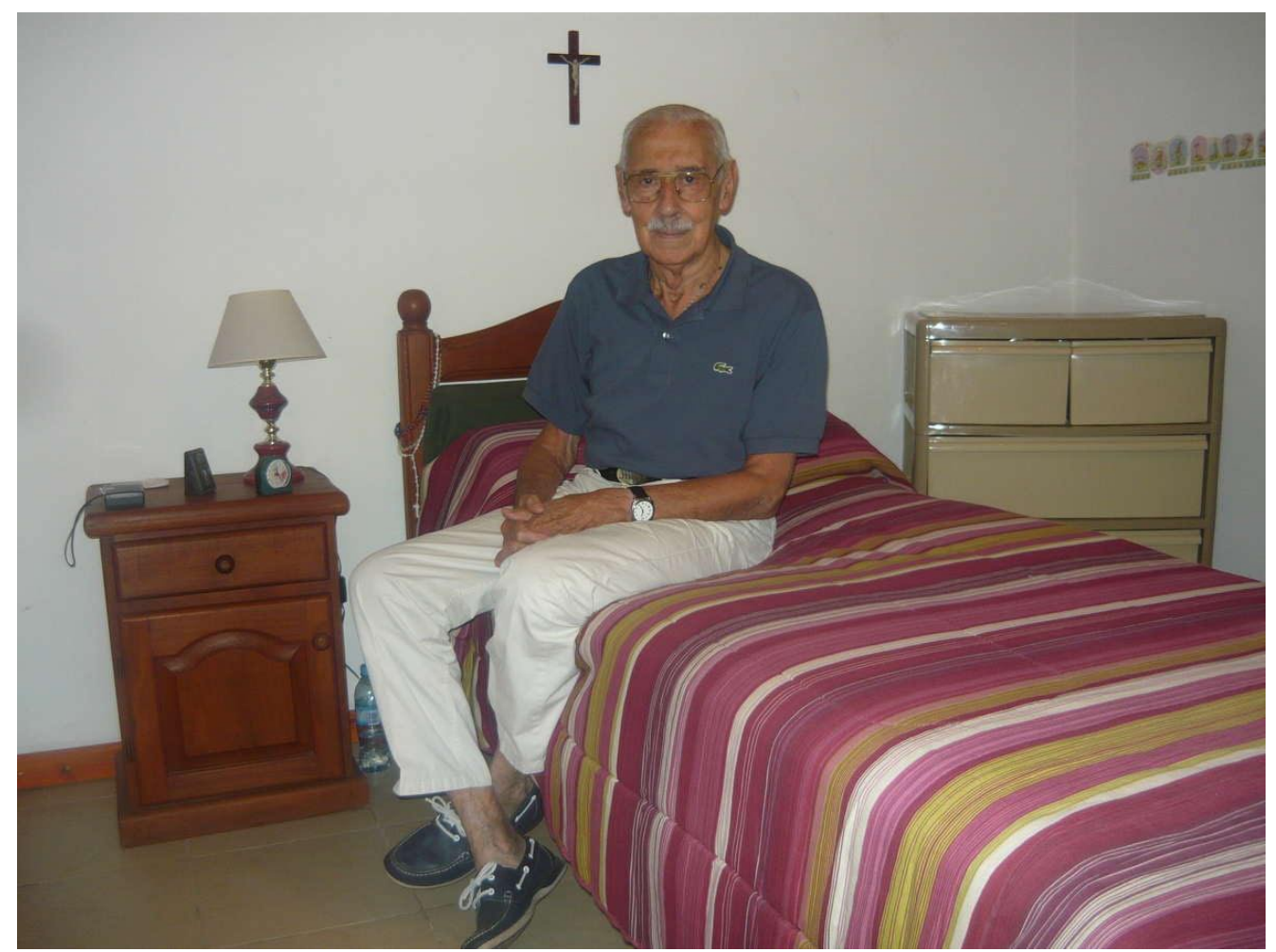

Autor de la foto: Ceferino Reato.

Figura 3

Miguel Etchecolatz al ser condenado por primera vez. Causa Etchecoltaz (2006)

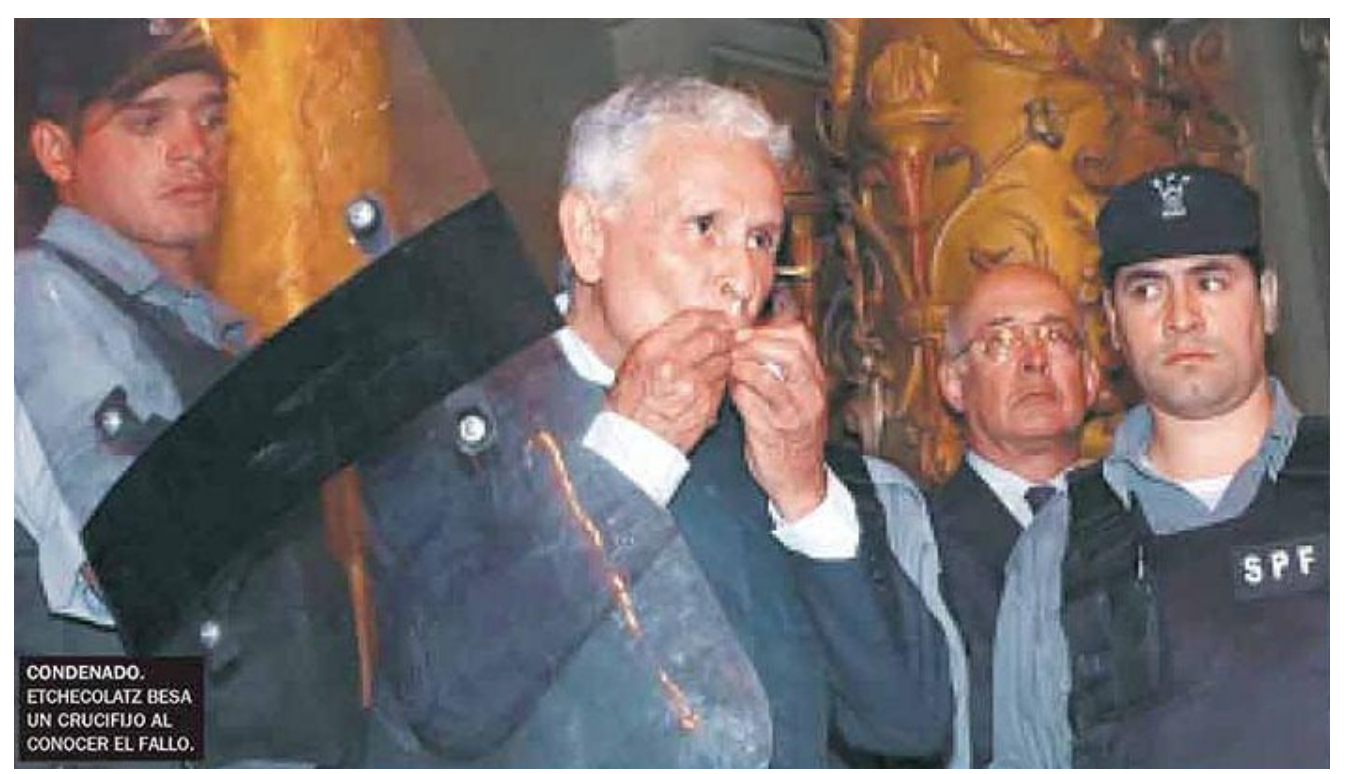

Autor de la foto: Daniel Forneri. 
Figura 4

Miguel Etchecolatz en una audiencia

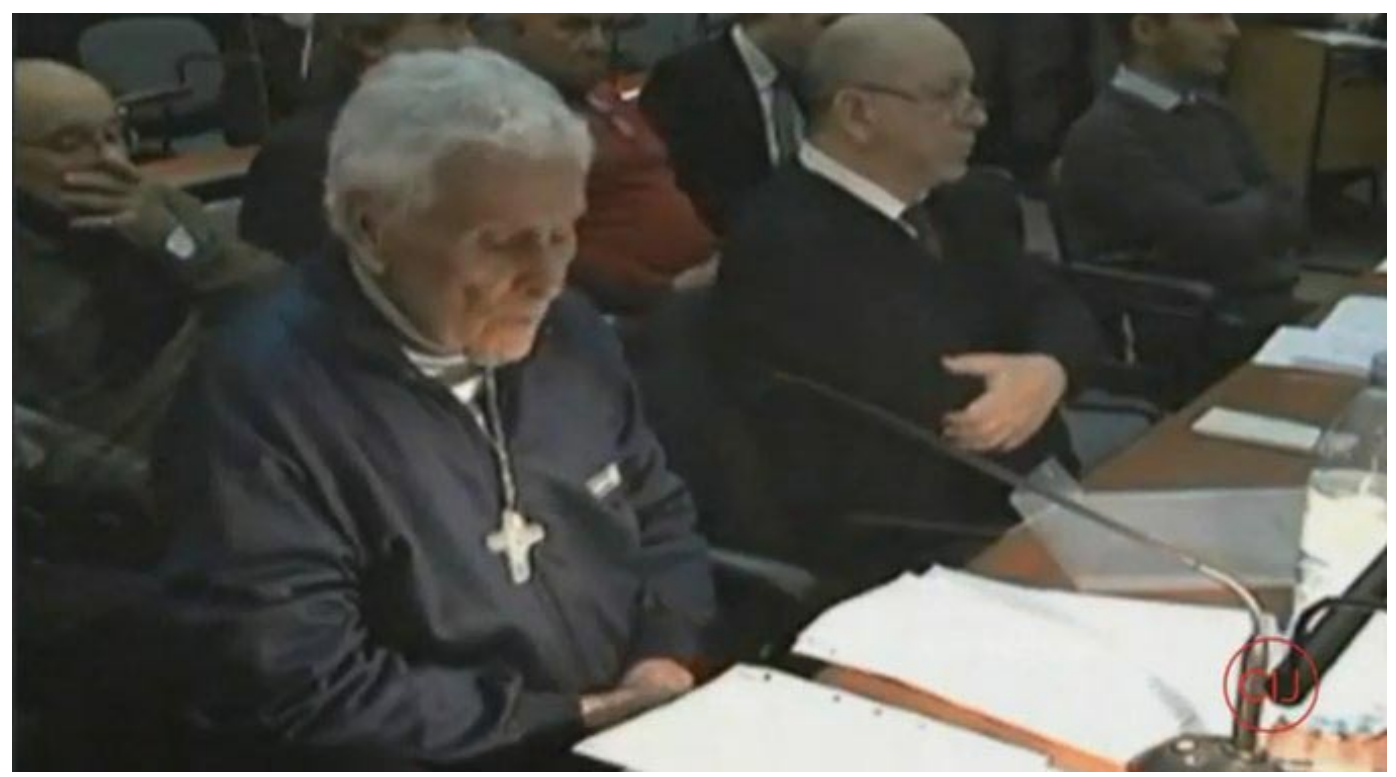

Autor/a: Anónimo (Centro de Información Judicial).

Figura 5

Collage sobre Miguel Etchecolatz en prisioneroenargentina.com ${ }^{31}$

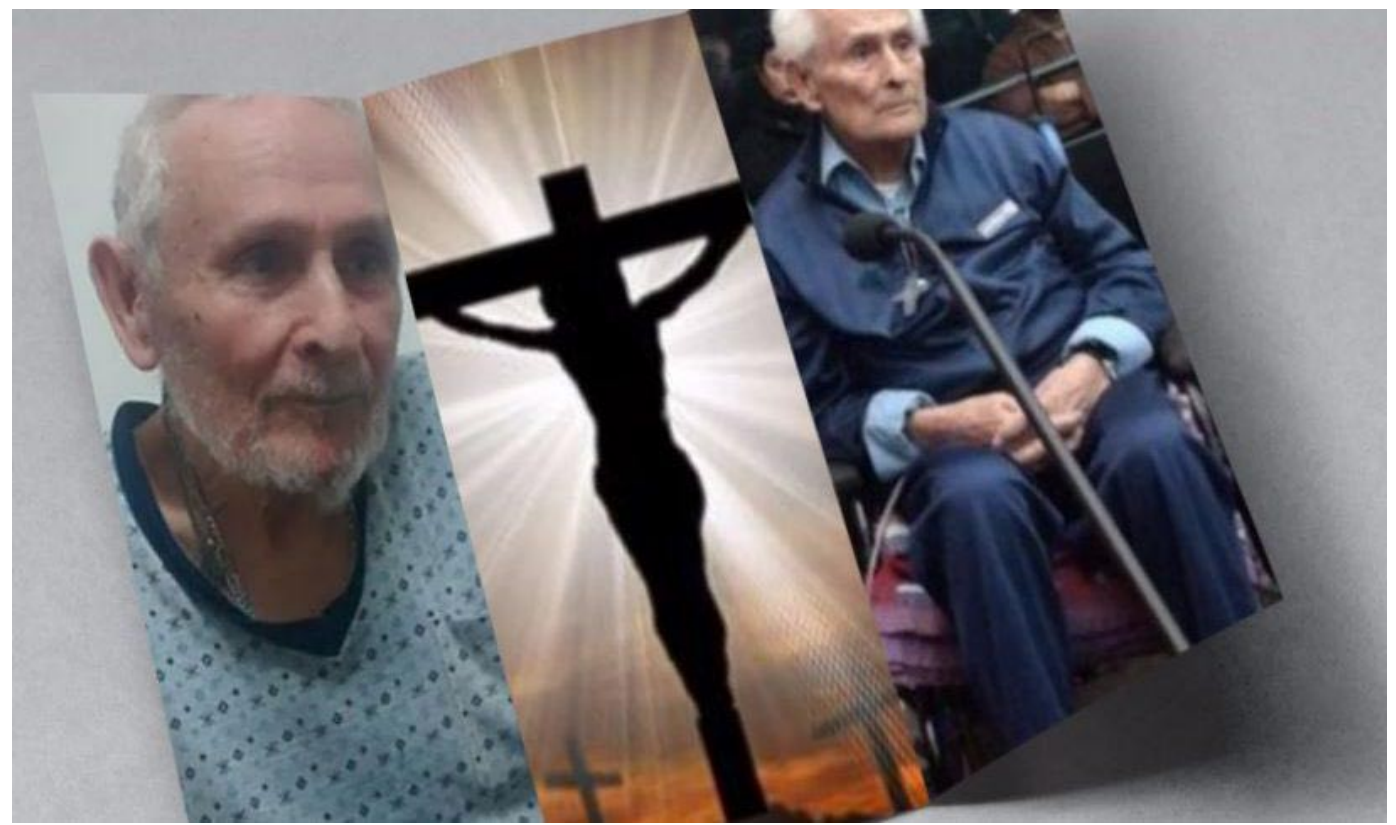

Autor/a: Anónimo.

31 Imagen disponible en: https://prisioneroenargentina.com/index.php/2017/10/27/la-tortura-consentida-porel-estado/. Última consulta: 28/08/2020. Este sitio web funciona como portal de notas de actualidad y opinión sobre política e historia argentina. Tiene un fuerte discurso conservador y de extrema derecha, revindicando tanto el accionar de la última dictadura militar como de las personas que la conformaron. 
Figura 6

Captura de pantalla durante la lectura de condena en la Causa Brigada de San Justo ${ }^{32}$ (2020)

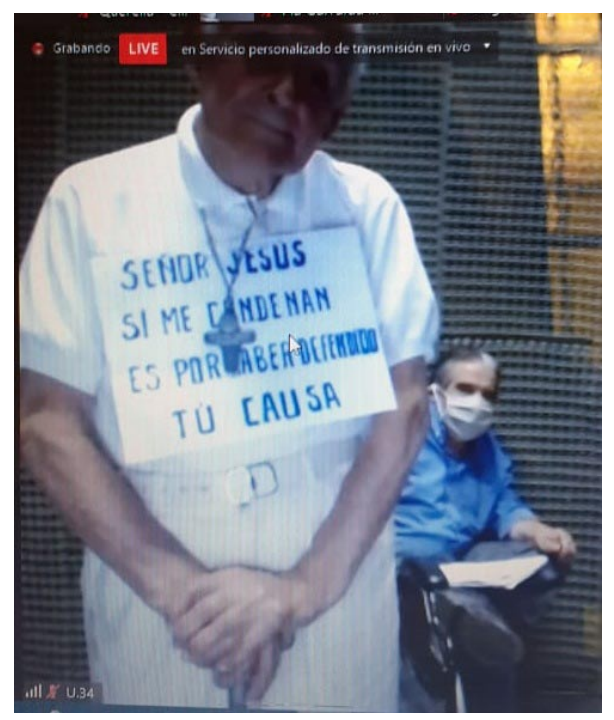

Estas imágenes poseen al menos un elemento recurrente: la presencia de una cruz. En la figura 1, ubicado compositivamente en el centro de la foto, vemos a Reynaldo Bignone, último presidente de facto de la dictadura, que con anterioridad había ocupado el cargo de $2^{\circ}$ Comandante y Jefe del Estado Mayor del Comando de Institutos Militares en Campo de Mayo, así como el de Comandante de los Institutos Militares. A pesar de tener su camisa cerrada casi hasta el cuello, una cruz dorada llama la atención por sobre su camisa azul. ¿Qué puede significar la cruz tan visible, tan "a mano»? Quizá Bignone la tocaba durante las audiencias, pero también ¿podría significar que lleva la cruz, que soporta el peso de la cruz? En la figura 2, el dictador Jorge Videla, comandante del Ejército y presidente de facto de la dictadura durante la primera y segunda Junta Militar, posa para la cámara del periodista Ceferino Reato en su prisión de Campo de Mayo. Una cruz, en la cabecera de la cama lo acompaña, lo resguarda y lo custodia. Videla, quien en numerosas ocasiones asumió la responsabilidad "propia del comandante» en "la victoria en la guerra contra la subversión» pero que negó su culpa por la muerte de miles de personas, era el «general más dispuesto a aceptar la doctrina del elegido, más proclive a creerse llamado a cumplir una misión divina» (Seoane y Muleiro, 2001: 46). Dicha actitud mesiánica la mantuvo no sólo durante sus períodos como presidente de facto sino también hasta los últimos años de su vida.

En las siguientes imágenes vemos a Miguel Etchecolatz. Comisario de la Policía de la Provincia de Buenos Aires, durante la dictadura fue Director de Investigaciones de la policía de dicha provincia y estrecho colaborador de Ramón Camps, militar que estuviera a cargo de la Policía de la Provincia de Buenos Aires durante el PRN. A Etchecolatz se lo acusó y condenó, entre otros crímenes, por el secuestro de un grupo de estudiantes durante la llamada «Noche los Lápices»"33, por apropiación de menores, homicidio agravado por ensañamiento

Durante el confinamiento a causa de la Covid-19 los juicios continuaron de forma virtual.

33 Se conoce como la "Noche de los Lápices» a los secuestros y asesinatos de estudiantes de secundaria, ocurridos durante la noche del 16 de septiembre de 1976 y días posteriores en la ciudad de La Plata (provincia de Buenos Aires). El hecho es un hito simbólico de las diversas políticas de memoria sobre la dictadura. En la dé- 
y alevosía, privación ilegítima de la libertad y tormentos. En un libro publicado en 1997, Etchecolatz se reconocía a sí mismo como un "guardador de preceptos divinos» (Etchecolatz, 1997: 124), un «iluminado de Dios» y un defensor de los «valores de la Patria»; también escribió que «nunca tuve ni pensé, ni me acomplejó culpa alguna» (Etchecolatz, 1997: 124). Su devoción cristiana y la (auto)percepción de haber llevado adelante una misión divina hace que la foto en la cual besa una cruz, luego de haber sido condenado, resulte mejor comprendida ${ }^{34}$.

Un denominador común en todas estas fotos se revela con mayor nitidez en el collage armado por el sitio web prisioneroenargentina.com: la representación de estos criminales como mártires. Los represores juzgados, en tanto que hombres de fe, hombres de Dios, aceptan llevar el peso de la cruz negándose a abjurar de sus creencias. Sostienen que no merecen ser juzgados porque sus actos fueron un servicio a la patria y Dios, no reconocen a la justicia civil como sus jueces naturales y siguen negando brindar información ${ }^{35}$. Su fe se asienta en creer que triunfaron en una guerra, que salvaron la patria y que por lo tanto no deben rendir cuentas sobre los crímenes cometidos. De este modo, el collage (figura 5) sobre Etchecolatz resulta significativo: a los costados dos fotos de un hombre viejo, de un ferviente creyente, de un "abuelito" en ropa de hospital asociando así edad con enfermedad; en el medio, una imagen de Jesús en la cruz creando en consecuencia una asociación inmediata. Para aquellos que promueven la prisión domiciliaria para los represores, incluso para aquellos que coinciden y apoyan el accionar criminal de la dictadura, Etchecolatz está siendo crucificado, siendo así un mártir. Esa idea se puede apreciar en forma aún más evidente en la figura 6, donde es el propio Etchecolatz quien manifiesta su «martirio».

Pero las cruces no son la característica exclusiva de esta fórmula; en la misma, además de la creencia religiosa, se combina una "violencia sobre los cuerpos" y un "comportamiento resignado pero convencido" (Burucúa y Kwiatkowski, 2014: 114) por parte de los mártires. En consecuencia, podemos pensar que para que el mártir alcance dicho estatus debe exhibir su cuerpo, debe mostrar cómo su cuerpo es sometido a la violencia. Esta exhibición, si entendemos los juicios como puestas en escenas (Kaufman, 1990), resulta parte de la performance que los represores llevan adelante tanto en las audiencias como en las afueras de los juzgados.

cada de 1980 se publicó un libro sobre el tema que se convirtió en un verdadero bestseller (La noche de los lápices de María Seoane y Héctor Ruiz Nuñez) que posteriormente, se adaptó al cine por Héctor Olivera en 1986 con el mismo título.

34 Las palabras pronunciadas por Etchecolatz en septiembre de 2006 en el juicio donde recibe su primera de las ocho condenas enmarcan esta idea. Como se recoge en La Nación: «yo sé que me van a condenar y que no van a tener vergüenza de condenar a un anciano, enfermo, sin dinero ni poder -expresó el expolicía一. Hizo una breve pausa y siguió, con tono desafiante: Pero, como dijo Borges, ustedes no son el juez. El juez supremo nos espera después de muertos... No es este tribunal el que me condena. Son ustedes los que se condenan». Disponible en: https://www.lanacion.com.ar/politica/condenaron-a-reclusion-perpetua-a-etchecolatz-nid841991/. Última consulta: 01/11/2020.

35 El 3 de noviembre de 2020, en el comienzo del Juicio por delitos de lesa humanidad cometidos en las Brigadas Policiales de Banfield, Quilmes y Lanús, cuando el presidente del tribunal le pregunta a Etchecolatz si tenía algo para decir, responde «tendría cosas para decir pero no voy a declarar porque sería convalidar la ilicitud de todos estos procedimientos». Disponible en: https://youtu.be//4xkpZCMSH4. Última consulta: $08 / 11 / 20$. 
Figura 7

Antonio Domingo Bussi en una audiencia (2010)

\section{Figura 8}

Bussi en una ambulancia tras descompensarse en una audiencia (2008)

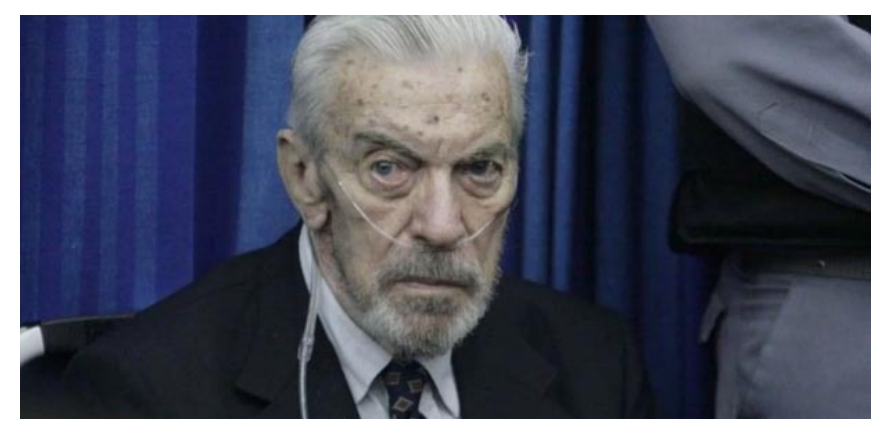

Autor/a: Anónimo.

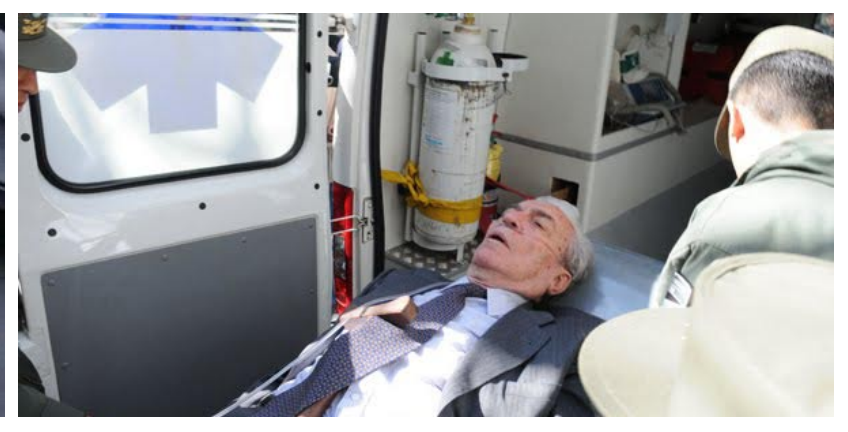

Autor/a: Anónimo.

Figura 9 (izq.) y Figura 10 (der.)

Luis Patti conducido en camilla a una audiencia. Tercer juicio de la Causa Campo de Mayo (2011)
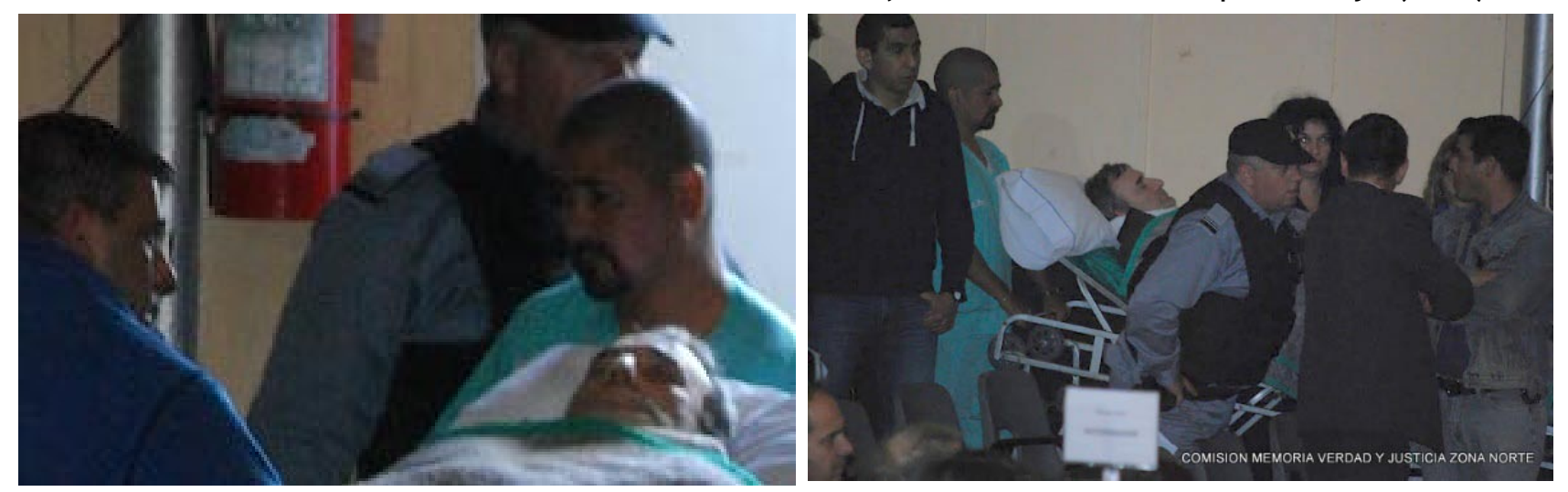

Fuente: Comisión Memoria Verdad y Justicia de Zona Norte.

En estas fotos podemos ver a Antonio Domingo Bussi (figuras 7 y 8) y Luis Abelardo Patti (figuras 9 y 10), dos represores que fueron conducidos a las audiencias en ambulancia. Estas imágenes, esta performance, donde la camilla funciona como una pieza de utilería de la puesta en escena de la defensa, han permitido también colocar a ambos acusados como los mártires ideales: sus cuerpos, más abatidos que el de otros represores, parecerían ser el territorio donde la justicia ejerce su violencia. Los cuerpos de Bussi y Patti, como el de Etchecolat $z^{36}$, condensarían la relación edad y enfermedad -y por lo tanto la imposibilidad de ser juzgados-. Con ello, se reconfigura la manera de percibir al perpetrador, trastocando cuerpo por persona, es decir, se impone la mirada sobre los cuerpos de Bussi y Patti, perdiendo de vista quiénes fueron ${ }^{37}$.

36 En el sitio prisioneroargentino.com, al pie de la imagen que comentamos, se exhibe una frase de Mahatma Gandhi que dice: «podrán torturar mi cuerpo, romper mis huesos e incluso matarme. Así, obtendrán mi cadáver. No mi obediencia». Para la hipótesis que aquí queremos desarrollar, resulta importante notar la operación que se hace para emparentar a un referente de la no violencia con un torturador.

37 Bussi fue comandante del III Cuerpo de Ejército con sede en la provincia de Córdoba, del I Cuerpo de Ejército con sede en Buenos Aires, comandante del Operativo Independencia en 1975 y gobernador de facto de la provincia de Tucumán durante la dictadura entre 1976 y 1978. Según la Comisión Bicameral Investigadora de la provin- 
Ahora bien, la fórmula del martirio como fórmula de representación de masacres y genocidios trae un problema teórico-metodológico (incluso ético, podríamos decir). Burucúa y Kwiatkowski señalan que "su uso [la de esta fórmula] es una prerrogativa exclusiva de las víctimas y sus partidarios, y está vedado a las estrategias justificatorias de los perpetradores» (2014: 115). ¿Debemos, entonces, dejar de lado esta perspectiva analítica? Ciertamente debemos tener en cuenta la dimensión ética que permite pensar y distinguir la representación de la víctima y la del victimario. Sin embargo, nos resulta sugerente observar que tanto los perpetradores como los sectores que los apoyan recurran a fórmulas de representación reservadas, según Burucúa y Kwiatkowski, a las víctimas. Al apelar a ello notamos un procedimiento singular por el cual primero se «neutraliza» la figura del represor, volviéndolo un «viejo»; luego, desde la mirada atravesada por los estereotipos del viejismo, la edad se vuelve sinónimo de enfermedad, llevando a que el represor pase a ser un viejo enfermo antes que un criminal; finalmente, en esa misma operación, el victimario deja de serlo para convertirse, en esa lógica discursiva, en la víctima, víctima además de la justicia. A partir de la conjunción de las imágenes mentales construidas a través de las palabras, —las editoriales de La Nación, por ejemplo- y lo visible de las fotografías se logra trastocar la prerrogativa de esta fórmula, haciendo que los represores sean vistos y comprendidos como víctimas y no como personas en pleno uso de sus facultades mentales que deciden, por ejemplo, no dar información sobre sus actos. Responsables de los crímenes más atroces, siguen siendo responsables hoy cuando eligen el silencio.

Creemos también que esta operación incluye otro aspecto a considerar: la empatía. Como señaló Edith Stein (2004), la empatía se refiere a la experiencia de la conciencia ajena y de sus vivencias, y al estudiar esta cuestión, Fritz Breithaupt (2011) se refiere a que la habilidad de ponernos en la piel de otra persona puede conducir con éxito a ula toma de partido». Efectivamente, uno de los elementos que permitiría la empatía es la similitud; sin embargo, según una de las hipótesis que plantea ese autor es que "dado que todo y nada puede ser similar, tal vez la empatía no sólo se produzca por similitud, sino limitando selectivamente esa similitud" (Breithaupt, 2011: 31). En esa dirección, al transformar a los perpetradores en mártires, en «enfermos» o en «abuelitos», se limita la similitud marginando los crimenes cometidos y su responsabilidad ante ellos. La empatía que permite alcanzar esta operación puede conducir a la posibilidad de pensar que estas personas están siendo juzgadas por causas injustas o por «simples» crímenes; en otras palabras, la forma de trabajar y permitir un posible lazo empático entre espectador y perpetrador lleva a clausurar la posibilidad de pensar que estas personas están siendo juzgadas por crímenes de lesa humanidad. De este modo, al clausurar esa perspectiva, dicha operación quiebra la cadena de la responsabilidad - no se puede responsabilizar al "pobre viejo»-, cuando, contrariamente, el represor que está siendo juzgado sigue siendo responsable por el crimen que cometió ${ }^{38}$.

cia de Tucumán, el 70\% de los 507 secuestros registrados en dicha provincia se produjeron durante los dos años de su gobierno. Acusado de privación ilegítima de la libertad y de la desaparición de personas, en uno de los juicios testigos aseguraron que el general Bussi se personaba en cada fusilamiento y daba la orden ejecutando con un disparo a la persona. Sin embargo, más allá de los años, Bussi nunca mostró arrepentimiento; su silencio en los tribunales - como parte del pacto de silencio entre los perpetradores-fue para algunos el signo de no doblegar su fe. Bussi logró en 2008 la prisión domiciliaria; al morir en 2011, el domicilio de reclusión era la casa de uno de sus hijos en el country del Jockey Club del selecto barrio Yerba Buena, en San Miguel de Tucumán.

38 Siguiendo a Paul Ricoeur (1997), pensamos la responsabilidad no solo como atribución —responsable de determinado acto - sino también en una dimensión temporal: se trata de ser responsable por las acciones pasadas como también de las consecuencias futuras que dicho acto produce. Los victimarios aquí juzgados no sólo son responsables por el asesinato, tortura, apropiación de bebés y desapariciones en el pasado; sino que con su silencio, con su negativa a brindar documentación o información sobre el destino de los cuerpos o de los bebés, el crimen se extiende en el presente y el futuro. 


\section{LA RETÓRICA EDAD-IMPUNIDAD A PARTIR DE LO NO VISTO: SEGUNDA APROXIMACIÓN}

Se afirma que la fotografía autentifica el pasado - el "esto ha sido» según Roland Barthes (2003) - y ante ella nos encontramos con la verdad y la oscuridad, con la exactitud y con el simulacro (Didi-Huberman, 2004); sin embargo, debemos tener en cuenta que la fotografía es un sistema convencional por el cual se le asigna determinados usos sociales y, ante todo, es el resultado de una mirada (Bourdieu, 2003). Esa mirada, a su vez, implica un recorte, para hacer visible algo al mismo tiempo se debe velar algo: la fotografía, la imagen, nunca es "total» ya que al mismo tiempo vemos y no vemos. Ahora bien, al observar fotografías de perpetradores mayores de edad, ¿qué tensiones emergen? ¿qué vemos/no-vemos? En las siguientes fotografías, justamente en lo no visto, encontramos algunas señales para seguir profundizando la «retórica edad-impunidad».

Figura 11

Eugenio Guañabens Perelló. Audiencia del séptimo juicio Causa Campo de Mayo (2012)

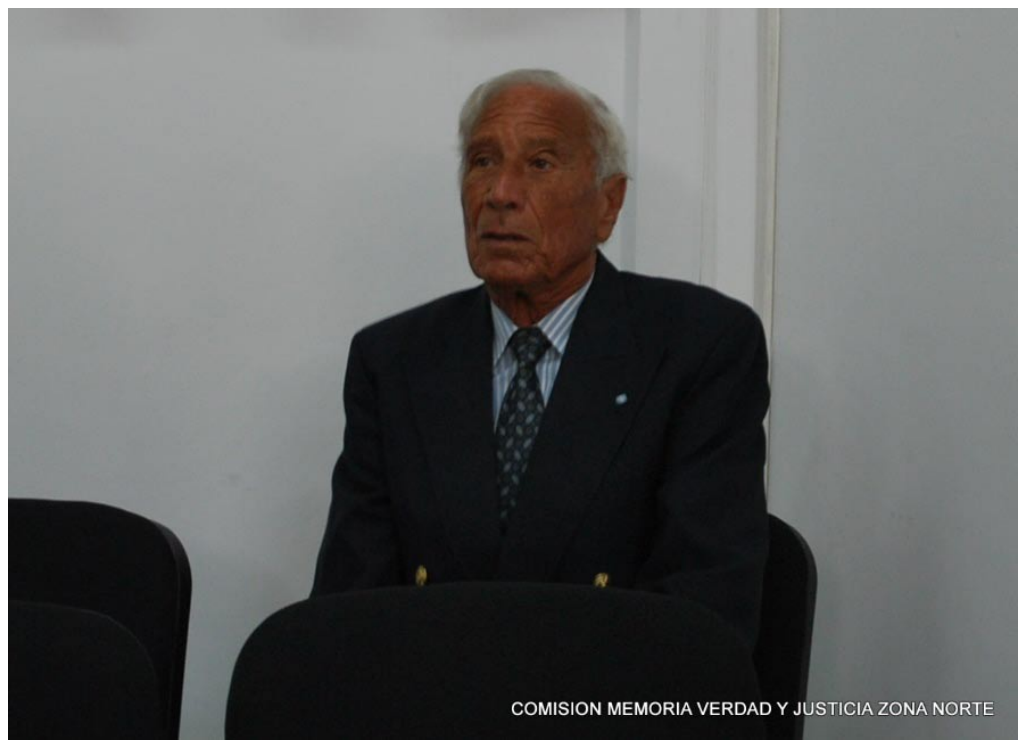

Autora de la foto: Marisú Hernández.

Este militar llegó a grado de general de división y fue sentenciado en abril de 2010 a 17 años de prisión por la comisión de delitos de lesa humanidad ${ }^{39}$. Prestemos atención a su cara. Aquí hablamos de cara y no de rostro porque no son en los gestos donde queremos reparar sino en su tez: ¿qué implica que una persona presa tenga un llamativo bronceado? La respuesta es indudable: estuvo en contacto con el sol. Entonces, si el perpetrador está en contacto con el sol, ello obliga a repensar nuestra representación social de cárcel. Si el encarcelado puede acceder al aire libre en contacto con el sol el tiempo suficiente para broncearse, implica que la cárcel no es un lugar oscuro ni un encierro en espacios diminutos. Efectivamente, los condenados por delitos de lesa humanidad tienen posibilidad, por ejemplo, de

39 Fue director de la Escuela General Lemos en la guarnición militar de Campo de Mayo. Al momento de su condena tenía 83 años. 
asistir a talleres ${ }^{40}$ y esa información, que forma parte del trato cotidiano que reciben en las cárceles, no circula en los medios de comunicación ya que han sido escasas las notas periodísticas que se han publicado en torno a la vida de los represores en las cárceles ${ }^{41}$. Sin embargo, en el año 2012 el periodista Ceferino Reato, en ocasión de entrevistar a Jorge Videla en la cárcel federal de Campo de Mayo para su libro Disposición Final, tomó varias fotografías que luego se hicieron públicas. Dos de ellas fueron utilizadas para la tapa de sus libros.

Figura 12

Portada del libro Disposición final de Ceferino Reato, primera edición (2012)

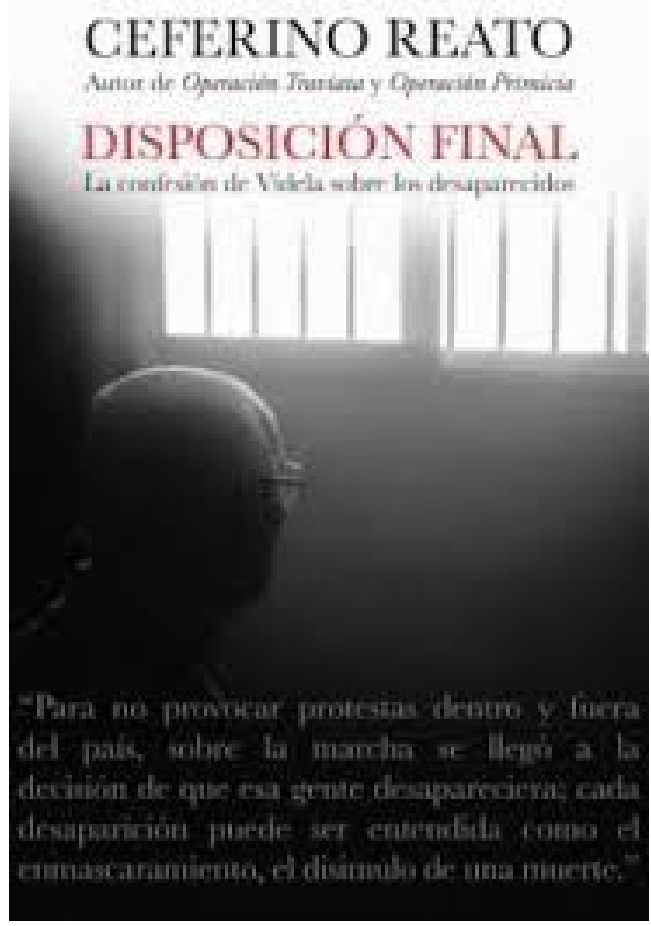

Figura 13

Portada del libro Disposición final de Ceferino Reato, edición definitiva (2016)

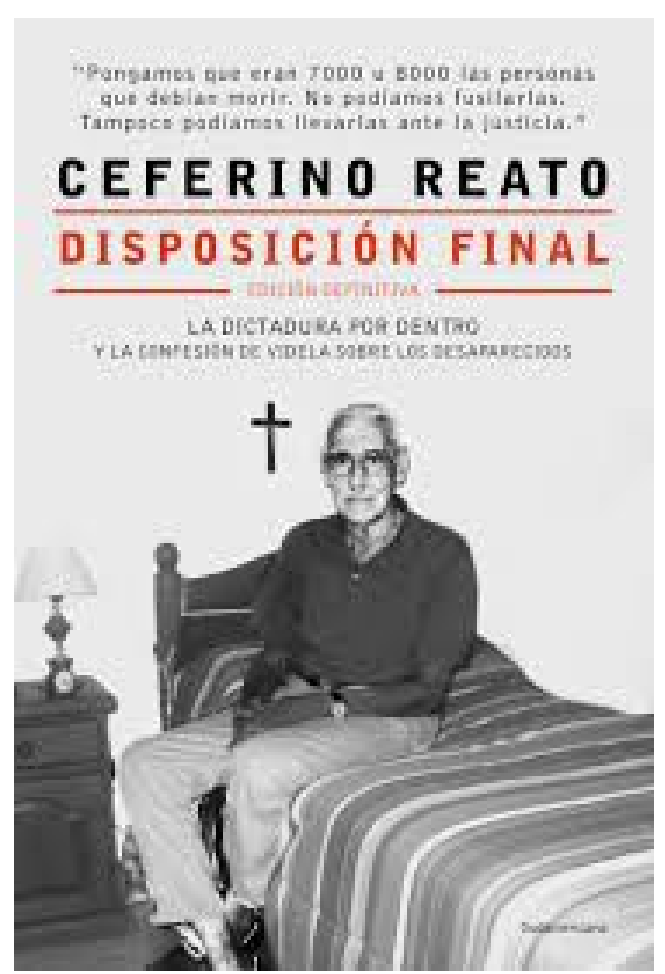

La del lado izquierdo pertenece a la primera edición publicada en el 2012; la de la derecha, a la edición definitiva del 2016. En consonancia con el subtítulo del libro - «la confesión de Videla sobre los desaparecidos» - la imagen de la primera edición nos sugiere a Videla siendo «iluminado» por una «luz divina» - quizá recibiendo la absolución luego de su confesión- que proviene de la ventana. Observemos, sin embargo, los barrotes que nos permitiría pensar en el espacio donde se encuentra confinado: esto es, una celda pequeña. La imagen de la segunda edición, que ya la vimos en una sección anterior, forma parte de una serie de fotografías que tomó el periodista y que circularon poco después del fallecimiento del dictador. Esta serie de fotos resultan únicas ya que es la primera vez que se ve a un perpetrador en su cárcel; en otras palabras, estas fotos permiten ver lo no visto, lo que se encontraba vedado a la mirada cotidiana.

40 Daniel Catalá, sobreviviente del Centro Clandestino de Detención Vesubio, ubicado en la provincia de Buenos Aires, declaró en la audiencia judicial del 28 de agosto de 2020, que era profesor de música en el servicio penitenciario federal y que coordinaba talleres de música para presos por delitos de lesa humanidad en el penal de Marcos Paz.

41 Al respecto, véase la nota de Alejandra Dandan del 28 de enero de 2018 en el portal El cohete a la luna. Disponible en: https://www.elcohetealaluna.com/yoga-lirica-represores-una-casaquinta-vip/. Último acceso: 01/11/2020. 
Figura 14

Imágenes de Jorge Videla
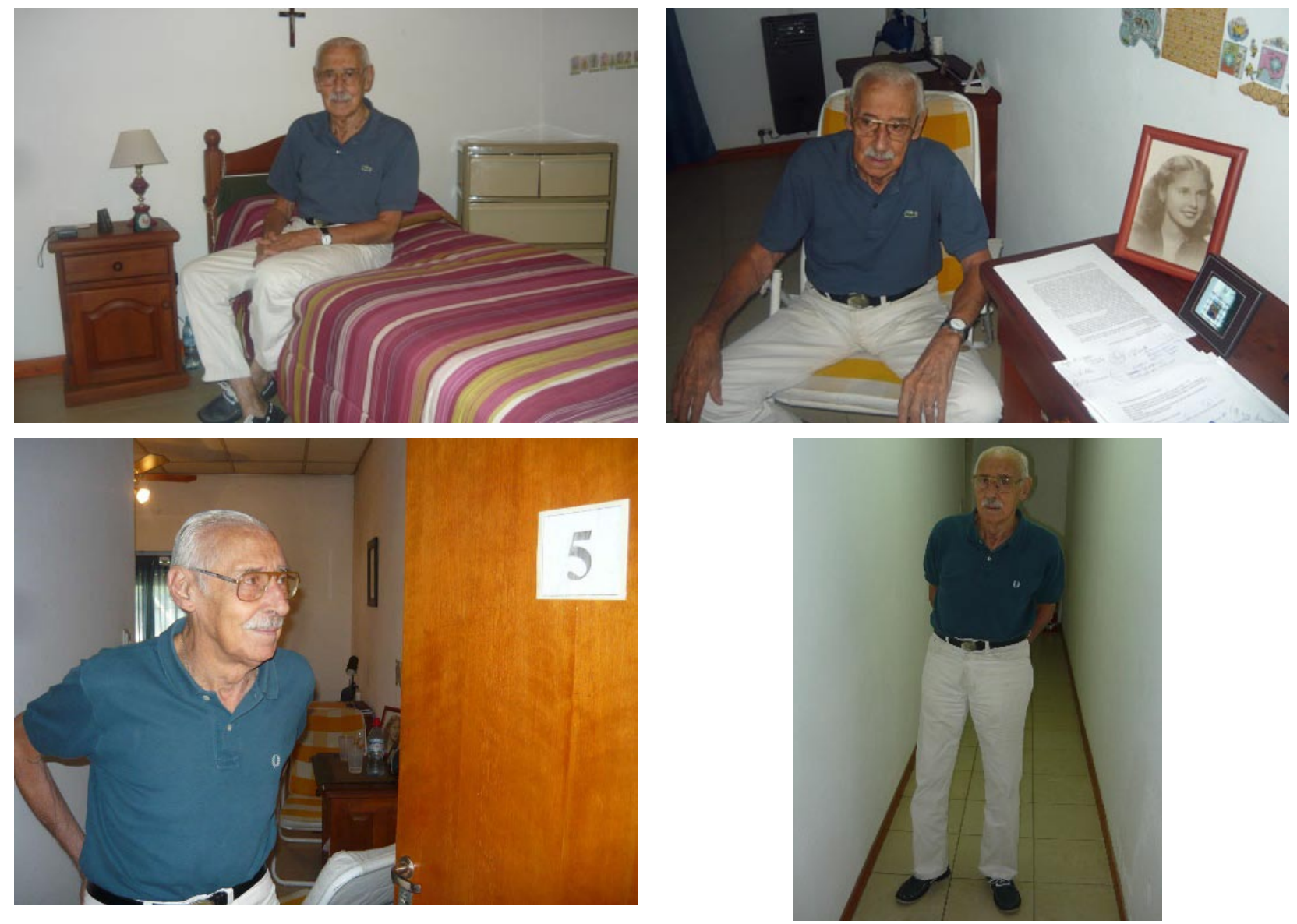

Autor: Ceferino Reato.

Esta serie de fotos quiebra de alguna manera la representación social que circula sobre las cárceles donde son alojados los perpetradores: no hay aquí celda diminuta, no hay barrotes, no hay traje a rayas para el condenado, no hay oscuridad ni precariedad -en la tercera foto podemos observar la luz que entra por la ventana y en la segunda, una estufa en la pared-. Las fotos de Videla en la cárcel se asemejan, quizá, a las de una persona mayor en un hogar de ancianos y con condiciones de vida óptimas. Asimismo, resulta importante observar en la segunda foto su escritorio de trabajo: una foto de su esposa de joven y dibujos de sus nietos denotan su contacto con el mundo exterior; a su vez, los propios papeles de trabajo de Videla nos permiten percibir que estamos ante un hombre en pleno uso de sus facultades intelectuales. Con todo, la sonrisa que asoma en algunas fotos, parte de las poses típicas de cualquier foto, como el nulo anclaje con el pasado que éstas poseen, conducen a neutralizar la idea de que estamos ante un antiguo dictador, llevándonos así a pensar que estamos ante un simple señor mayor, y no ante el responsable de las dos juntas militares más criminales que tuvo la Argentina. Si las fotos no portan consigo mismas su sentido ${ }^{42}$, una operación atra-

42 Philippe Dubois señaló que las fotografías no tienen significación en sí mismas ya que éste es exterior a ellas. Retomando a Barthes, Dubois (1986: 51) apunta que el uesto ha sido no nos dice esto quiere decir; en consecuencia, la imagen fotográfica no tendría otra semántica que su propia pragmática». 
yente a realizar es traer el pasado al presente. Es decir, producir una especie de «montaje de atracciones ${ }^{43}$ para alcanzar un choque, un conflicto, haciendo emerger lo no visto en lo visto.

Figura 15

Luciano Benjamín Menéndez en una audiencia de juicio oral por delitos de lesa humanidad

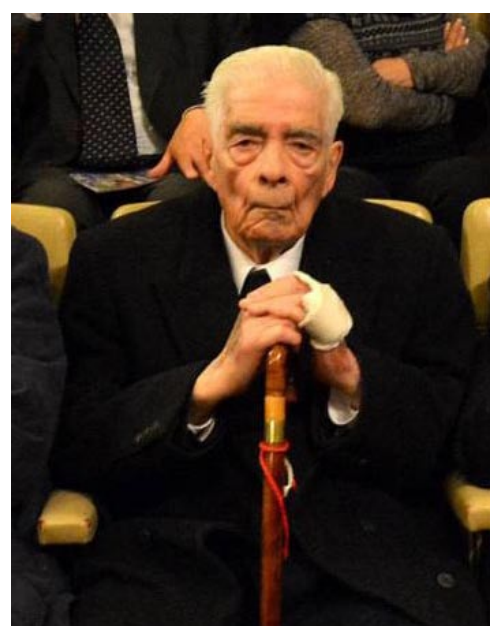

Autor de la foto: Daniel Cáceres.
Figura 16

Luciano Benjamín Menéndez enfrentando, cuchillo en mano, a un grupo de Madres de Plaza de Mayo al salir del Canal 13 en 1984

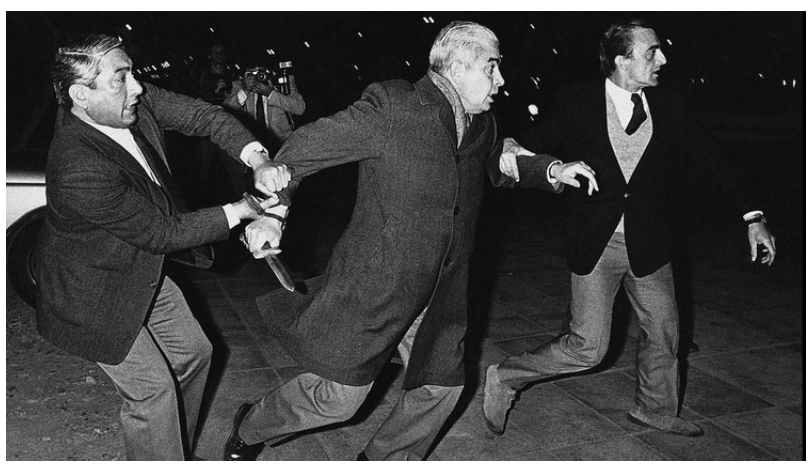

Autor de la foto: Enrique Rosito.

En la figura 15 vemos a un "pobre abuelito», con bastón y una mano herida, en una audiencia de juicio oral por delitos de lesa humanidad. Al observar esa imagen todo espectador debe tener en cuenta, por ejemplo, la figura 16: el mismo «abuelito" con un puñal. Se trata de Luciano Benjamín Menéndez, quien estuvo a cargo de la zona de defensa III, condenado 13 veces a prisión perpetua. La foto de la derecha fue tomada por el reportero gráfico Enrique Rosito de la agencia periodística DyN el 21 de agosto de 1984; esa noche Menéndez salía del Canal 13 donde había sido entrevistado en un programa de televisión; afuera, en la calle, un grupo de Madres de Plaza de Mayo repudiaban su presentación. En consecuencia, Menéndez se bajó de su auto y enfrentó a las Madres cuchillo en mano - cuchillo reglamentario del ejército- hasta que su hijo y un custodio lo detuvieron. La foto no sólo muestra un acto de violencia sino también al propio perpetrador ejerciéndola; en otras palabras, la foto es una muestra del poder y de la impunidad que este militar presumía detentar aún en democracia.

Este es quizá el componente principal no visto que las imágenes permiten mostrar: el poder que los perpetradores pueden aún detentar ${ }^{44}$. Ese poder se manifiesta en la negativa en brindar información sobre el destino de miles de desaparecidos, como el caso de bebés apropiados, haciendo que el crimen se continúe perpetuando en el tiempo; ello hace que estos "abuelitos» puedan ser considerados aún hoy en día como perpetradores. ¿Pero cómo puede manifestarse en la imagen ese poder? Quizá sea en la siguiente imagen donde podamos apreciar ello.

43 Para el cineasta soviético Sergei Eisenstein (1994), dicho montaje se caracterizaba por buscar un choque emotivo, un conflicto, entre toma y toma, creando como resultado un nuevo sentido.

44 Si bien los acusados no son necesariamente actores políticos de relevancia - la probabilidad de que un nuevo golpe militar suceda en Argentina es una posibilidad remota-, sí detentan un poder simbólico, sobre todo para los diversos grupos y sectores que apoyan y reivindican el genocidio perpetrado por la dictadura. 
Figura 17

Audiencia del juicio La Cacha en La Plata (2014)
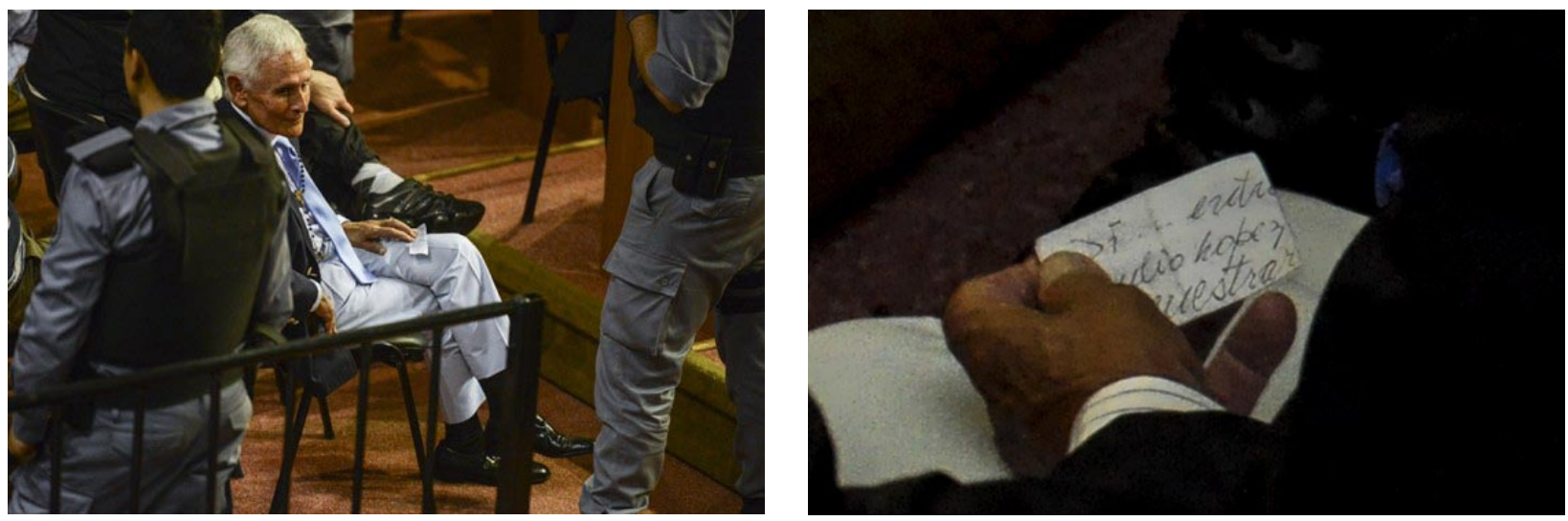

Fotos: Leo Vaca.

En la foto de la izquierda vemos nuevamente a Miguel Etchecolatz durante el juicio que tuvo lugar en el 2014 por La Cacha, uno de los CCDTyE que funcionó en La Plata ${ }^{45}$ durante la última dictadura. En el momento en el que se estaba leyendo el veredicto, Etchecolatz miró a los familiares de las víctimas y a los organismos de Derechos Humanos y sacó de su bolsillo un papel doblado que desplegó lentamente. El fotógrafo que tomó la foto, Leo Vaca, luego agrandó la imagen para darse cuenta de que allí estaban escritas las palabras «Jorge Julio López» y "secuestrar»: dicho papel hacía referencia al segundo secuestro y desaparición de Julio López. En efecto, en el 2006, horas antes de la lectura del veredicto que condenaba a Etchecolatz "por delitos de lesa humanidad cometidos en el marco de un genocidio", fue secuestrado nuevamente el sobreviviente Jorge Julio López, testigo fundamental en aquel juicio. Desaparecido hasta el día de la fecha, se cree que Etchecolatz estuvo vinculado, aún desde la cárcel, en su desaparición. De este modo, el mensaje no sólo tiene un tinte mafioso, sino que es un signo de impunidad ante la desaparición de Julio López como también una muestra del poder que Etchecolatz detentaba aún estando condenado y en prisión.

\section{A MODO DE CIERRE}

En el presente trabajo nos propusimos reparar en la dimensión visual de lo que hemos denominado "retórica edad-impunidad"; un tipo de retórica que emergió como estrategia discursiva con el fin de lograr una morigeración de las penas, prisiones domiciliaras o, incluso, alcanzar la inimputabilidad.

Asimismo, esta perspectiva nos ha permitido reparar en, al menos, dos cuestiones. Por un lado, en el discurso estereotipado sobre el que se monta la defensa de los represores que están siendo juzgados; por otro lado, este estereotipo, al asociar vejez con enfermedad e incapacidad, neutraliza el tipo de crimen que se está juzgando: delitos de lesa humanidad. Se instala así una imagen del represor viejo en el presente, eximido de toda responsabilidad en el pasado, como si la persona actual no tuviera vínculo alguno, en términos identitarios, con la del pasado.

45 Capital de la provincia de Buenos Aires. 
Al reparar en la edad de los acusados hicimos ingresar el concepto de viejismo a fin de asumir una perspectiva crítica sobre el tema, ello nos ha permitido observar cómo el victimario trastoca la responsabilidad volviéndose víctima. Dicha cuestión, desde ya, no resulta una novedad puesto que es la matriz típica que emerge en la narrativa de los perpetradores (Baumeister, 1999). Nuestra intención, entonces, ha radicado en advertir cómo se ha ido desplegando dicho trastocamiento en el marco de los juicios. En esa dirección, a partir del análisis de la «fórmula del martirio", hemos visto cómo dicho modo de representación, reservado históricamente para las víctimas, ha sido apropiado por los perpetradores y por quienes apoyan, en última instancia, sus crímenes. En consecuencia, al recurrir a dicha fórmula de representación, la «retórica edadimpunidad» en su dimensión visual intenta sintetizar dos niveles: el narrativo y el emotivo.

La principal consecuencia de esta retórica quizá sea que al intentar hacer foco en la edad de los acusados - afirmando que lo que se lleva adelante no es justicia sino una aberración ya que no se tiene piedad ante los «pobres viejos»-queda desplazado el crimen cometido. Por ende, la retórica edad-impunidad lleva a negar por qué se los está juzgando y las características del crimen cometido.

Como han sugerido numerosos autores, el genocidio es ante todo un proceso (Rosenberg, 2012) que se da en el tiempo y que no culmina en el momento del exterminio; de hecho, el aniquilamiento es una de las etapas más avanzadas, pero no necesariamente la última. En ese sentido, al no haber podido acceder los familiares de las víctimas a la información respecto al paradero de los desaparecidos y de los bebés nacidos en cautiverio, el crimen continúa ejecutándose. Ello nos lleva a remarcar que los «abuelitos» que están siendo juzgados por crímenes que cometieron en el pasado, deberían serlo también por su ejecución presente. La retórica edad-impunidad conduce así a neutralizar responsabilidades pasadas y actuales favoreciendo la impunidad gerontológica.

Finalmente, pensamos que el recorrido aqui presentado puede resultar un aporte a los debates en torno al juzgamiento por los crimenes cometidos durante el genocidio, a los debates sobre la representación de los perpetradores y a las estrategias empleadas por éstos para exculparse y asegurar la impunidad. Poner en tensión lo visto y lo no visto permite desarmar dicha retórica y no olvidar que la responsabilidad por los crímenes de lesa humanidad excede la edad.

\section{BIBLIOGRAFÍA}

Barthes, R. (2003). La cámara lúcida. Nota sobre la fotografía. Buenos Aires: Paidós.

Baumeister, R. (1999). Evil. Inside Human Violence and Cruelty. Nueva York: W. H. Freeman and Company.

Borrelli, M., y González, M. (2012). El diario La Nación ante la reapertura de los juicios por violaciones a los derechos humanos en Argentina (2003-2007). Oficios Terrestres, 1(28), 1-26.

Bourdieu, P. (2003). Un arte medio. Ensayo sobre los usos sociales de la fotografía. Barcelona: Gustavo Gili.

Breithaupt, F. (2011). Culturas de la empatía. Buenos Aires: Katz.

Britton, R. (1994). Realidad psíquica y creencia inconsciente. Revista de Psicoanálisis, 51(1-2), 27-34. 
Burucúa, J.E., y Kwiatkowski, N. (2014). «Cómo sucedieron estas cosas». Representar masacres y genocidios. Buenos Aires: Katz.

Butler, R. (1969). Age-Ism: Another Form of Bigotry. The Gerontologist, 9(4.1), 243-246.

CONADEP-Comisión Nacional sobre la Desaparición de Personas (1984). Nunca más. Buenos Aires: EUDEBA.

Crocco, N. (2020). Legitimidad, impunidad y justicia. La prensa escrita y el proceso de juzgamiento por crímenes de estado en Argentina (2003-2019) (Tesis doctoral inédita). Universidad de Buenos Aires, Buenos Aires.

Didi-Huberman, G. (2004). Imágenes pese a todo. Barcelona: Paidós.

Dubois, P. (1986). El acto fotográfico. Barcelona: Paidós.

Eisenstein, S. (1994). El sentido del cine. México: Siglo XXI.

Etchecolatz, M. (1997). La otra campana del Nunca Más. s/d.

Feierstein, D. (2007). El genocidio como práctica social. Buenos Aires: FCE.

Jodelet, D. (1984). La representación social: Fenómenos, conceptos y teoría. En S. Moscovici (Ed.). Psicología Social II (pp. 469-494). Barcelona: Paidós.

Junta Militar (1980). Documentos básicos y bases políticas de las fuerzas armadas para el proceso de reorgaización nacional. Buenos Aires: Congreso de la Nación. Disponible en: https://apm.gov.ar/periplosdememorias/1-1-B-1.html.

Kaufman, E. (1990). El ritual jurídico en el juicio a los ex comandantes. La desnaturalización de lo cotidiano. En R. Guber (Ed.). El salvaje metropolitano (pp. 328-357). Buenos Aires: Legasa.

Organización Mundial de la Salud (2015). Informe mundial sobre el envejecimiento y la salud. Ginebra: Publicaciones de la Organización Mundial de la Salud.

Programa Verdad y Justicia (2015). Impunidad Gerontológica. Aportes para abogados quereIlantes en causas de crimenes contra la Humanidad. Buenos Aires: Ministerio de Justicia y Derechos Humanos de la Nación.

Ricoeur, P. (1997). El concepto de responsabilidad. Ensayo de análisis semántico. En Lo justo (pp. 39-68). Santiago: Editorial Jurídica de Chile.

Rosenberg, S. (2012). Genocide Is a Process, Not an Event. Genocide Studies and Prevention: An International Journal, 7, 16-23.

Salvarezza, L. (1996). Psicogeriatría. Teoría y clínica. Buenos Aires: Paidós.

Salvi, V. (2012). De vencedores a víctimas. Memorias militares sobre el passado reciente en la Argentina. Buenos Aires: Biblos.

Seoane, M., y Muleiro, V. (2001). El dictador. La historia secreta y pública de Jorge Rafael Videla. Buenos Aires: Sudamericana.

Stein, E. (2004). Sobre el problema de la empatía. Madrid: Trotta.

Taboada, A. (2016). Los juicios por delitos contra la humanidad y la salud: Entre el derecho y la impunidad. En IX Seminario Internacional Políticas de la Memoria. Centro Cultural de la Memoria Haroldo Conti, Buenos Aires. 